\title{
Activity-Based Costing Analysis for Train Station's Service
}

\author{
Anucha Watanapa ${ }^{1, a, *}$, Siwadol Pholwatchana ${ }^{2}$, and Wisitsree Wiyaratn ${ }^{3}$ \\ 1 Department of Production Technology Education, Faculty of Industrial Education and Technology, King \\ Mongkut's University of Technology Thonburi, Bangkok 10140, Thailand \\ 2 Freight Transport Laemchabang Station Container Transport Bureau, The State Railway of Thailand \\ 3 Faculty of Industrial Education and Technology, King Mongkut's University of Technology Thonburi, \\ Bangkok 10140, Thailand \\ *E-mail: Anucha.wat@kmutt.ac.th
}

\begin{abstract}
Laem Chabang train station is subsidiary to container transportation office of The State Railway of Thailand. Its operation is divided into two main parts: Laem Chabang station and Laem Chabang Port station operates 24 hours a day. This report does research on services of both stations that can be categorized into two types: container train service and oil train services which are different in their processes. This report analyses activitybased costing especially in the Laem Chabang train station's direct expense which does not include other organizations' expenses such as mechanical department, civil department or signalling department. Formerly, The State Railway of Thailand had not been calculating this kind of cost, the workgroup thus attempts to make activity-based costing of Laem Chabang train station to improve its service procedure and reduce its future cost. From calculation cost of service of Laem Chabang train station by applying activity-based costing, the cost of activity for each type of train is revealed. The cost of service for oil train is $1,575.85$ baht per train, for container train entering zone B port is 809.61 baht per train and for container train entering zone $C$ port is 811.76 baht per train. It is found that cost of service for oil train is the highest due to its lower client which is about one-eighth of container train. In order to reduce cost, it can be considered to operate more oil trains or to decrease the number of labour related to oil train because labour salary is about $83 \%$ of the total cost. Thus, optimization of labour can clearly lower overall cost.
\end{abstract}

Keywords: Activity-Based costing, train station cost of service, container transportation, optimization.

ENGINEERING JOURNAL Volume 20 Issue 5

Received 26 October 2015

Accepted 8 March 2016

Published 25 November 2016

Online at http://www.engj.org/

DOI:10.4186/ej.2016.20.5.135 


\section{Introduction}

Activity-based costing (ABC) is a new cost management system which encourages the executives' interest in importance of costing and activity management, and simultaneously informs useful information for better product costing, cash and liquidity management and decision than traditional cost accounting system [1-2]. The information is in form of more reliable product and production cost. At the same time, it notifies the executives what activity is worth for business process and product. When look at the big picture, $A B C$ is the method which helps costing be more accurate i.e. $\mathrm{ABC}$ identifies activities related to production of each category of product by analyzing resources used by the activity and activity driver of each activity. It can thus clearly determine resource usage of each product. $A B C$ is different from the traditional method as it uses the activity instead of cost center [3]. In addition, $A B C$ helps costing allocation to be more accurate by using numerous allocation criteria. Banomyong et al., (2006)[4] introduced a research on 'logistic cost control using cost accounting system' which was done by using activities based costing to study production industry management system for improving production management which focused on production cost data, and to find out more accurate unit cost by using canned sweet corn as a case study. Akkarachaipanit (2001) [5] researched on activity costing of logistic business for the purpose of capability of more accurately analyzing activity cost, cost-to-serve and customer cost of one operator who do business by accumulating merchandises from its customer in suburb area and then deliver to the destination in other province. The research developed activity cost model in 5 steps covering all activities in administration, warehouse and transportation department. Moreover, the model can express cost caused by car usage separately in outward trip and return trip. It can also show useful managing of car's capacity and the cost caused by ineffective use.. Adil Baykasoglu and Vahit Kaplanoglu (2008) [6] studied implementation of ABC in Turkey land transportation. This research used AHA procedure together with $\mathrm{ABC}$ to select cost driver to improve performance of spreading overheads to activities which makes cost analyzing be more effective to land transportation firm when compared to traditional costing system. According to "Activity-based costing in distribution business" (Worawattananon, 2005) [7], ABC concept has been used in many businesses because it can show the actual cost of operation which helps to plan strategies properly. However, one reason why this concept has not been widely used in distribution business is because of limitation of knowledge in developing and implementing $\mathrm{ABC}$ in practice. This research thus aim at understanding the process of developing $\mathrm{ABC}$ and its implementation to reveal the cost of distributing each product. The study collected information of cost and activities done by one distributor which distribute consumer product to the destinations in any provinces in Thailand. The research showed that, for the case of sharing resources to hand out product, $\mathrm{ABC}$ is a tool that can help analyze exact cost of distribution, and help identify sources of the cost which assist the operator in managing the cost and planning strategies. In addition, even if the resources are not shared, the model can be used to analyze data to monitor efficiency of resource usage which can be considers as one of the way to advance internal processes and activities. There are 5 reasons $A B C$ is useful for management: 1. It makes product/service costing more accurate. 2. It makes performance measurement more effective. 3. It is cost reduction. 4. It is decision support for executives. 5. It provides organization's continuous improvement. Laem Chabang train station is subsidiary to container transportation office of The State Railway of Thailand. Its main objective is to provide services to container and oil trains. There are about $900-1000$ container trains and about 120 oil trains (inboundoutbound) using the services each month. Its operation is divided into two main part: Laem Chabang station and Laem Chabang Port station. There are two parts in its operation. The first is support part performed by, for example, station masters and clerks who work in shifts of twelve hours. Another part is operation part performed by, for example, shuntman, marshalling operator, train dispatchers who work in shifts of eight hours. In Laem Chabang station, there are five workers in each shift: one station master, one shuntman, one marshalling operator, one security officer and one dispatcher. In Laem Chabang Port station, there are seven workers in each shift: one station master, one clerk, one shuntman, one marshalling operator and three dispatchers.

This report studies on service procedures of the two parts of Laem Chabang train station. There are two types of services which are different in activities: container train service and oil train service. It analyzes only activity-based costing of the expenses caused directly by the station which does not include other organizations' expenses such as mechanical department, civil department or signaling department. Formerly, The State Railway of Thailand had not been calculating this kind of cost, the workgroup thus attempts to make activity-based costing of Laem Chabang train station to improve its service procedure and reduce its future cost. The concept of ABC Model is shown in Fig. 1. A vertical path and track costs is 
described using resources into activities by pushing the appropriate resources when calculating the cost of the activity. Therefore, activity-based costing to consider things like cost of living driven cost management refers to the horizontal oriented activities. For further details about the performance of the activities by causing the activity or driving costs, which will lead to an operational unit in the form of non-monetary. Evaluation workshops (Operating Measure), which is the process of cost due to the activities of vertically.

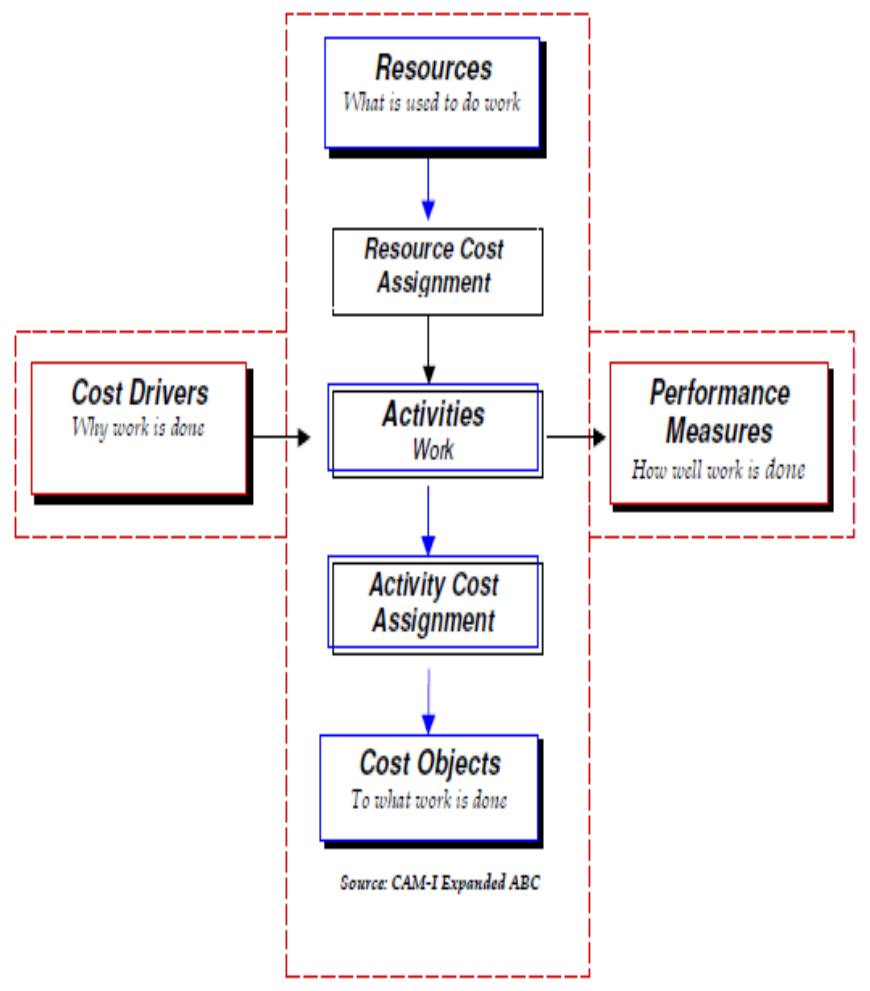

Fig. 1. ABC Model by the Consortium for Advance Manufacturing-International (CAM-I) in 1991 [8].

\section{Activity-Based Costing Methodology}

In private sector, activity-based costing is a way to allocate resources cost of an organization based on production or service activities provided for customers. ABC is a tool which can provide understanding in product cost, customer cost and benefits so it is used to support strategic decision making such as pricing, outsourcing and process measurement. Figure 2 shows activity-based costing is earmarked for expenses related to the cost of the activities involved in the process of production and services. Step action: Step 1 is to identify or determine the activity. Step 2 the cost of inputs or resources is calculated. Step 3 put the cost of the resources used in each is calculated in step 2 and distributed according to each activity based on number of practical steps to implement. Step 4 import data of costing of activities. Step 5 data collection and the amount of each activity is done. Step 6 the cost per unit of activity is calculated by bringing the total cost of each activity divided by the volume of work.

Traditional product assessment is based on values of direct labour, direct material and compute overhead costs in the form of a ratio. This method works especially for factor with less diverse products. However, for more product variety factory, overhead costs are apparently more dominant as can be seen from, for example, setup, indirect material and design cost. Therefore, $A B C$ is a new method used to compensate that vulnerability by estimating cost from various activities such as production and finance which relate to the product. Activity-based costing methodology $(\mathrm{ABC})$ is based on two hypotheses:

(1) Resources will be used when an activity occurs.

(2) The activity is product-oriented. 


\subsection{Implementation of $\mathrm{ABC}$ Consists of Six Steps:}

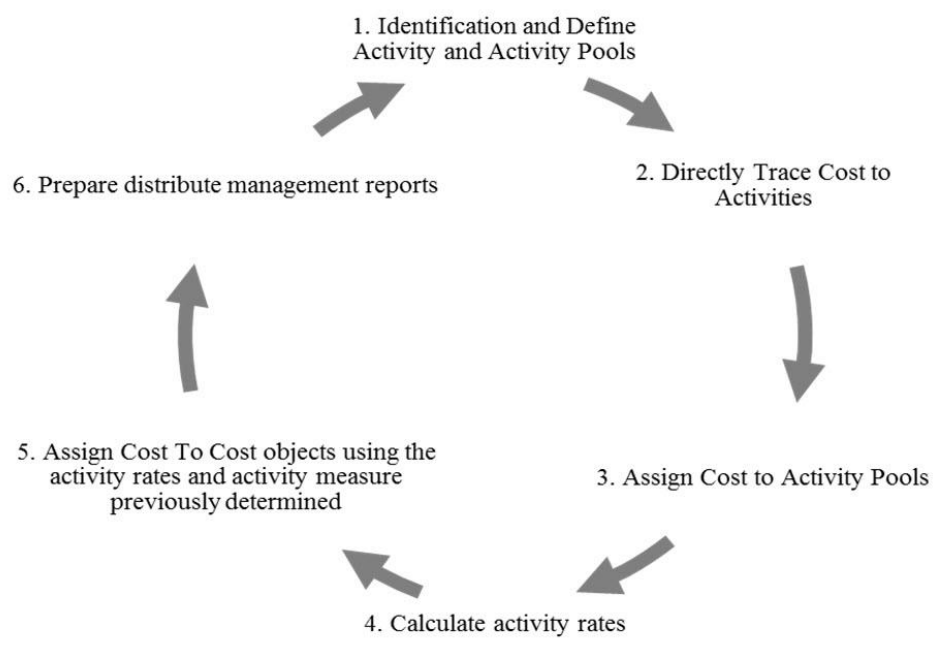

Fig. 2. Six steps required to implement an ABC system: Ray Garrison and Eric W. Noreen (1999) [9].

\subsection{Interview and Data Collection}

Research methodology on activity-based costing of Laem Chabang train station services is focused on compiling gathered data, making and analyzing information to improve management of logistic part of the organization since it has been using only traditional costing. To reveal the actual cost of servicing activities, the researchers hence solely study on cost associated with the station services by applying activity-based costing in analyzing so the organization adapt the output to improve its process in providing competitiveness in global market.

2.2.1. Study, interview and collect data from operation of employees in organization units and department

2.2.2. Study servicing procedure of Laem Chabang train station

For operational processes of the station, there are two part of execution, at Laem Chabang station and at Laem Chabang Port. It consists of seven steps:

Processes Step 1: reception of trains at Laem Chabang station: receive both container and oil trains, inform traffic controller of time schedule and coordinate to rotate train crew's shift.

Processes Step 2: train waiting for service: in case of Laem Chabang Port station is not available; the trains have to wait at Laem Chabang station.

Processes Step 3: reception of trains at Laem Chabang Port station: receive only container trains, record the arrival time

Processes Step 4: shunting operation: shunt in between the train

Processes Step 5: container train coordination. When the train is placed at the loading point, there will be coordination to freight operators to perform freight operation, documentation, statistical summary, collecting freight.

Processes Step 6: dispatch of trains from Laem Chabang Port station: dispatch trains from Laem Chabang Port station to Laem Chabang station

Processes Step 7: dispatch of trains from Laem Chabang station: dispatch trains from Laem Chabang station to their destination 


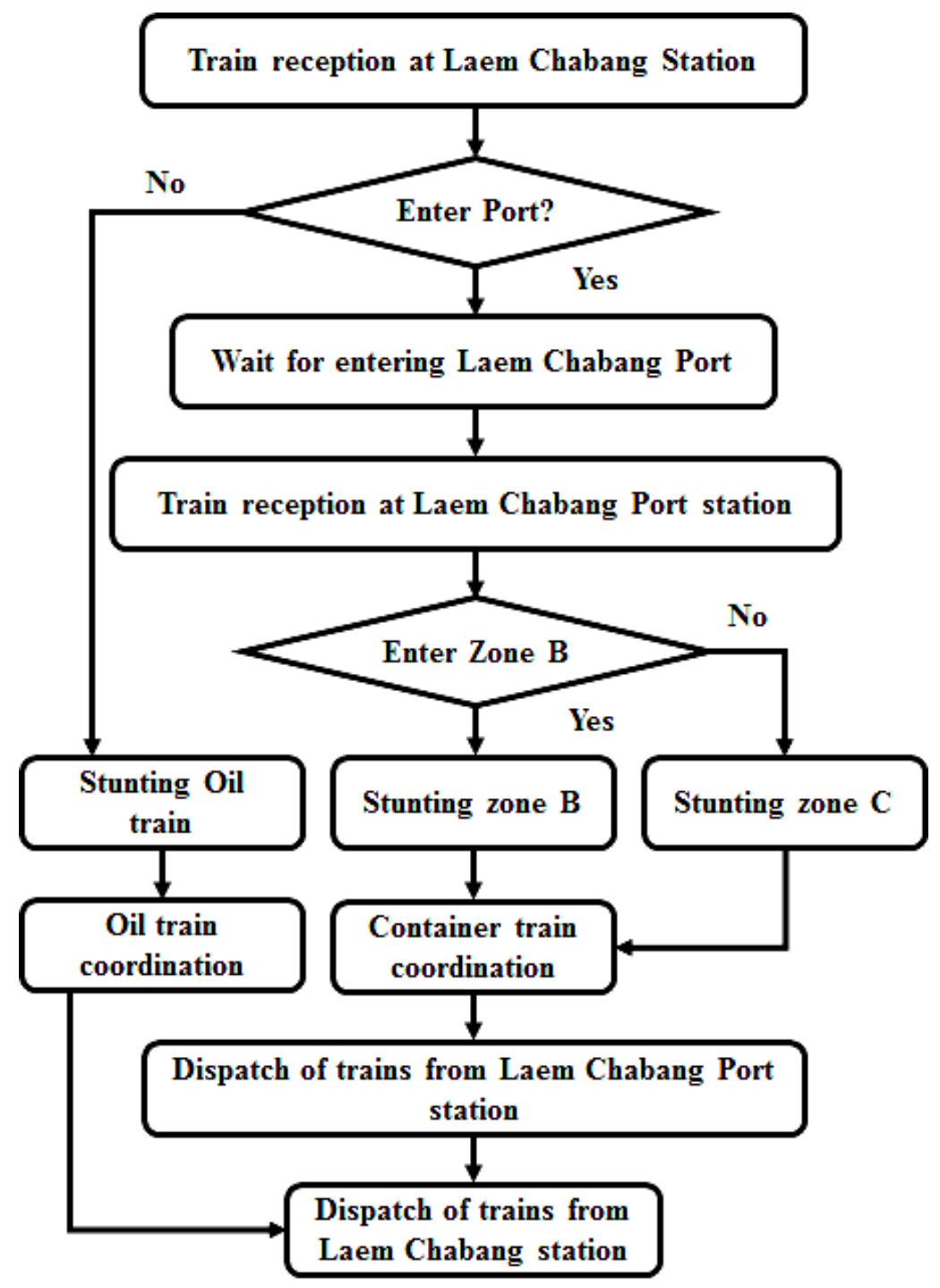

Fig. 3. Flow chart of service for oil train.

\section{Research Results and Discussion}

\subsection{Research on Activity-Based Costing of Laem Chabang Train Station}

There are three types of services: 1) service for oil train zone A 2) service for container train entering zone $\mathrm{B}$ port 3) service for container train entering zone $\mathrm{C}$ port. Therefore, main services provided by the station can be categorized into three types as mentioned above which will be recognized as service A, B and C accordingly as shown in Table 1 . The whole process can be described in a flow chart as shown in Fig. 3 . The convoy arrived at Laem Chabang station consists of two types of vehicle convoy of oil and a fleet of cargo trucks. In case of a convoy of crude oil train reaches the station in Laem Chabang, a convoy of crude oil will be delivered to the station next to the shunt. If a container train is forwarded to the Laem Chabang station, it will inform the station employees correctly if the train will dock to dock Zone B or Zone C. The container train will then switch back to the train station at Laem Chabang station. Laem Chabang station will coordinate to launch a fleet of crude oil and container in the convoy to return. 
Table 1. Relation between process and type of service.

\begin{tabular}{llll}
\hline \multirow{2}{*}{ No. } & \multicolumn{1}{c}{ Activity } & \multicolumn{2}{c}{ Type of service } \\
\cline { 3 - 4 } & & A & B \\
\hline 1 & Reception of trains at Laem Chabang station & \\
\hline 2 & Train awaiting for service & & \\
\hline 3 & Reception of trains at Laem Chabang Port station & \\
\hline \multirow{3}{*}{4} & Shunting & Crude oil \\
\cline { 3 - 4 } & & Zone B & \\
\hline 5 & Marshalling & Crude oil \\
\cline { 3 - 4 } & Container \\
\hline 6 & Dispatch of trains from Laem Chabang Port station \\
\hline 7 & Dispatch of trains from Laem Chabang station \\
\hline
\end{tabular}

Remark: $\square=$ Perform operation; $\square=$ Not perform operation.

\subsection{Research on Production Cost Classified by Resources}

Three months retroactive study on expense caused at the station is conducted. The cost which is composed of labor wages from both operation and supporting staff and both Laem Chabang station and Laem Chabang Port station, and overhead costs is analyzed and classified into group of similar expenses.

Expense of the station is mainly from labor wages; additional expense is from cost of utilities such as water, electricity, security, transportation fee for zone C staff and office supplies. The recorded expense is summarized in Table 2. Moreover, the workgroup has gathered working data of Laem Chabang train station workers in many forms such as hours of work and waiting time of trains as shown in Table 3, which is to be used for costing in next steps.

Table 2. Expense of Laem Chabang train station.

\begin{tabular}{|c|c|c|c|c|c|c|}
\hline \multirow{2}{*}{ No. } & \multirow{2}{*}{ Expense } & \multirow{2}{*}{$\begin{array}{l}\text { April } \\
2013\end{array}$} & \multirow{2}{*}{$\begin{array}{l}\text { May } \\
2013\end{array}$} & \multirow{2}{*}{$\begin{array}{l}\text { June } \\
2013\end{array}$} & \multicolumn{2}{|c|}{ Total } \\
\hline & & & & & Baht & Percent \\
\hline 1 & $\begin{array}{l}\text { Laem Chabang station's supporting staff } \\
\text { wage }\end{array}$ & 68,433 & 64,291 & 63,343 & 196,067 & $6.63 \%$ \\
\hline 2 & $\begin{array}{l}\text { Laem Chabang Port station's } \\
\text { supporting staff wage }\end{array}$ & 205,300 & 192,872 & 190,029 & 588,200 & $19.90 \%$ \\
\hline 3 & $\begin{array}{l}\text { Laem Chabang station's } \\
\text { shuntman wage }\end{array}$ & 107,083 & 99,072 & 94,031 & 300,185 & $10.16 \%$ \\
\hline 4 & $\begin{array}{l}\text { Laem Chabang Port station's } \\
\text { shuntman wage }\end{array}$ & 401,562 & 371,518 & 352,614 & 1125,695 & $38.08 \%$ \\
\hline 5 & $\begin{array}{l}\text { Gasoline fee for marshaling operator of } \\
\text { Laem Chabang Port station zone C }\end{array}$ & 49,200 & 51,000 & 49,800 & 150,000 & $5.07 \%$ \\
\hline 6 & Security expense & 34,300 & 34,300 & 34,300 & 102,900 & $3.48 \%$ \\
\hline 7 & $\begin{array}{l}\text { Cost of utilities (water, electricity and office } \\
\text { supplies) }\end{array}$ & 164,880 & 162,109 & 165,766 & 492,755 & $16.67 \%$ \\
\hline & Total expense (Baht) & $1,030,758$ & 975,161 & 949,883 & $2,955,802$ & $100.00 \%$ \\
\hline
\end{tabular}

*Source: Laem Chabang train station payroll account, Laem Chabang train station cash book.

\subsection{Cost-to-Activity Allocation Criteria}

To allocate costs to activities, there must be criteria of cost driver in which each category has been assigned criteria for cost allocation. In this report, there are two main criteria: hours of work of staff and waiting time of trains at Laem Chabang station. A cost-to-activity allocation criterion is described in Table 4. 
Table 3. Work load of Laem Chabang train station for cost drivers.

\begin{tabular}{clccccc}
\hline \multirow{2}{*}{ No. Item } & \multirow{2}{*}{ Unit } & \multicolumn{4}{c}{ Work load } \\
\cline { 4 - 7 } & & & $\begin{array}{c}\text { April } \\
\mathbf{2 0 1 3}\end{array}$ & $\begin{array}{c}\text { May } \\
\mathbf{2 0 1 3}\end{array}$ & $\begin{array}{c}\text { June } \\
\mathbf{2 0 1 3}\end{array}$ & Total \\
\hline 1 & Hours of work of Laem Chabang station staff & Hour & 2,880 & 2,976 & 2,880 & 8,736 \\
2 & Hours of work of Laem Chabang Port station staff & Hour & 5,040 & 5,208 & 5,040 & 15,288 \\
3 & Hours of work of security officer & Hour & 720 & 744 & 720 & 2,184 \\
4 & Hours of work of zone C staff & Hour & 3,600 & 3,720 & 3,600 & 10,920 \\
5 & Total hours of work & Hour & 8,640 & 8,928 & 8,640 & 26,208 \\
6 & Waiting time of trains at Laem Chabang station & Minute & 10,302 & 9,486 & 8,160 & 27,948 \\
\hline
\end{tabular}

*Source: Hours of work is calculated using workers' working time, Trains' waiting time is accumulated from Laem Chabang station's token book.

Table 4. Cost-to-activity allocation criteria.

\begin{tabular}{|c|c|c|c|}
\hline No. & Item & Cost allocation criteria & $\begin{array}{l}\text { cost driver } \\
\text { (unit) }\end{array}$ \\
\hline \multicolumn{4}{|c|}{ 1. Staff wage } \\
\hline 1.1 & $\begin{array}{l}\text { Laem Chabang station's supporting staff } \\
\text { wage }\end{array}$ & Hours of work of station staffs & 8,736 Hours \\
\hline 1.2 & $\begin{array}{l}\text { Laem Chabang Port station's } \\
\text { supporting staff wage }\end{array}$ & $\begin{array}{l}\text { Hours of work of Port station } \\
\text { staffs }\end{array}$ & 15,288 Hours \\
\hline 1.3 & $\begin{array}{l}\text { Laem Chabang station's } \\
\text { shuntman wage }\end{array}$ & Hours of work of station staffs & 8,736 Hours \\
\hline 1.4 & $\begin{array}{l}\text { Laem Chabang Port station's } \\
\text { shuntman wage }\end{array}$ & $\begin{array}{l}\text { Hours of work of Port station } \\
\text { staffs }\end{array}$ & 15,288 Hours \\
\hline 1.5 & $\begin{array}{l}\text { Gasoline fee for marshaling operator of } \\
\text { Laem Chabang Port station zone C }\end{array}$ & Hours of work of zone $C$ staffs & 10,920 Hours \\
\hline \multicolumn{4}{|c|}{ 2. Security expense } \\
\hline 2.1 & Security expense & Waiting time of trains & 27,948 Minutes \\
\hline \multicolumn{4}{|c|}{ 3. Cost of utilities } \\
\hline 3.1 & $\begin{array}{l}\text { Cost of utilities (water, electricity and office } \\
\text { supplies) }\end{array}$ & $\begin{array}{l}\text { Total hours of work of all } \\
\text { staffs }\end{array}$ & 26,208 Hours \\
\hline
\end{tabular}

Cost divers shown in the table comes from:

(1) Hours of work of staff which are calculated from number of workers for each duty multiply with 24

(2) Waiting time of trains which is summarized from transportation statistics

\subsection{Activity-Based Costing Calculation}

After collecting all categorized service costs and computing cost driver, full costing is divided into activitybased costing which is as shown in Table 5 . 
Table 5. Cost allocation.

\begin{tabular}{|c|c|c|c|c|c|c|}
\hline \multirow{2}{*}{ No. } & \multirow{2}{*}{\multicolumn{2}{|c|}{ Activity }} & \multicolumn{3}{|c|}{ Service cost (Baht) } & \multirow{2}{*}{ Total } \\
\hline & & & Labor & Security & Utilities & \\
\hline 1 & \multicolumn{2}{|c|}{ Reception of trains at Laem Chabang station } & $412,089.16$ & - & - & $412,089.16$ \\
\hline 2 & \multicolumn{2}{|l|}{ Train awaiting for service } & - & 102,900 & - & 102,900 \\
\hline 3 & \multicolumn{2}{|c|}{$\begin{array}{l}\text { Reception of trains at Laem Chabang Port } \\
\text { station }\end{array}$} & $262,238.56$ & - & - & $262,238.56$ \\
\hline \multirow{3}{*}{4} & \multirow{3}{*}{ Shunting operation } & Crude oil & $149,850.60$ & - & - & $149,850.60$ \\
\hline & & Zone B & $262,238.56$ & - & - & $262,238.56$ \\
\hline & & Zone C & $187,313.25$ & - & - & $187,313.25$ \\
\hline \multirow{2}{*}{5} & \multirow{2}{*}{ Train coordination } & Crude oil & $149,850.60$ & - & $179,183.64$ & $329,034.24$ \\
\hline & & Container & $262,238.56$ & - & $313,571.36$ & $575,809.92$ \\
\hline 6 & \multicolumn{2}{|c|}{$\begin{array}{l}\text { Dispatch of trains from Laem Chabang Port } \\
\text { station }\end{array}$} & $262,238.56$ & - & - & $262,238.56$ \\
\hline 7 & \multicolumn{2}{|c|}{ Dispatch of trains from Laem Chabang station } & $412,089.15$ & - & - & $412,089.15$ \\
\hline \multicolumn{3}{|c|}{ Total } & $2,360,147$ & 102,900 & 492,755 & $2,955,802$ \\
\hline
\end{tabular}

The cost allocation is calculated from each activity cost multiplied with actual work load of the activity and then divided by total work load of the category. Any activity which cannot be categorized will not be calculated for costing.

\subsection{Activity Cost Assignment}

This step is to assign total expense of each activity to a variable which is a number of trains serviced by each activity. The workgroup has collected number of trains which is served by the station from time record of the station master for three months as well as accumulated expense as shown in Table 6 . The trains will run into different processes.

Table 6. Number of trains served by each activity.

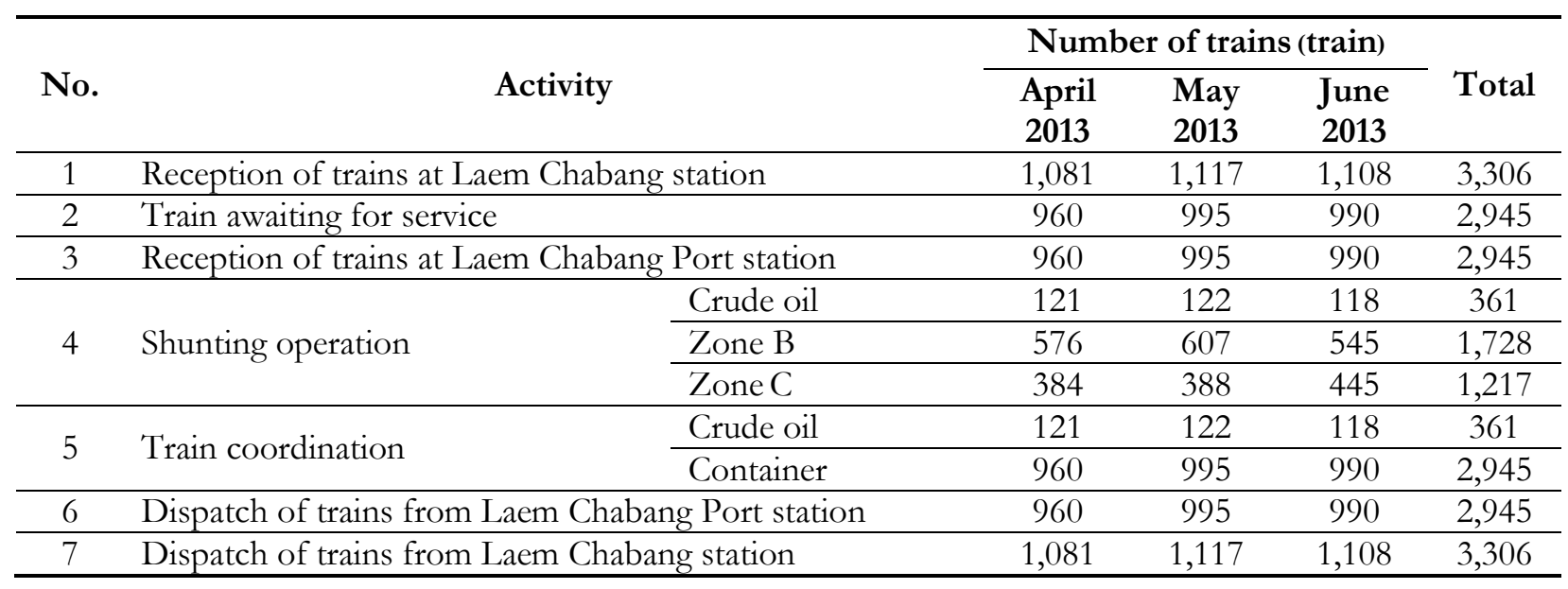


Cost of service can then be calculated by dividing expense of each activity by number of trains served by the activity. The cost of service is shown in Table 7 .

Table 7. Assignment of cost to train service.

\begin{tabular}{|c|c|c|c|c|c|}
\hline No. & \multicolumn{2}{|c|}{ Activity } & $\begin{array}{l}\text { Activity-based cost } \\
\text { (Baht) }\end{array}$ & $\begin{array}{c}\text { Number of } \\
\text { trains } \\
\text { (Train) }\end{array}$ & $\begin{array}{c}\text { Cost of } \\
\text { service } \\
\text { (Baht/Train) }\end{array}$ \\
\hline 1 & \multicolumn{2}{|c|}{$\begin{array}{l}\text { Reception of trains at Laem Chabang } \\
\text { station }\end{array}$} & $412,089.16$ & 3,306 & 124.6489 \\
\hline 2 & \multicolumn{2}{|c|}{ Train awaiting for service } & $102,900.00$ & 2,945 & 34.9406 \\
\hline 3 & \multicolumn{2}{|c|}{$\begin{array}{l}\text { Reception of trains at Laem Chabang } \\
\text { Port station }\end{array}$} & $262,238.56$ & 2,945 & 89.0454 \\
\hline \multirow{3}{*}{4} & \multirow{3}{*}{ Shunting operation } & Crude oil & $149,850.60$ & 361 & 415.0986 \\
\hline & & Zone B & $262,238.56$ & 1,728 & 151.7584 \\
\hline & & Zone C & $187,313.25$ & 1,217 & 153.9139 \\
\hline \multirow{2}{*}{5} & \multirow{2}{*}{ Train coordination } & Crude oil & $329,034.24$ & 361 & 911.4522 \\
\hline & & Container & $575,809.92$ & 2,945 & 195.5212 \\
\hline 6 & \multicolumn{2}{|c|}{$\begin{array}{l}\text { Dispatch of trains from Laem Chabang } \\
\text { Port station }\end{array}$} & $262,238.56$ & 2,945 & 89.0454 \\
\hline 7 & \multicolumn{2}{|c|}{$\begin{array}{l}\text { Dispatch of trains from Laem Chabang } \\
\text { station }\end{array}$} & $412,089.15$ & 3,306 & 124.6489 \\
\hline
\end{tabular}

From studying to find cost of service per train of Laem Chabang train station, the cost of activity per train has been revealed as shown in Table 7. However, there are three types of train served at the station; the train is served by different processes depending on its type (as in Table 1). Cost of service per train for each type is summarized in Table 8.

Table 8. Cost of service per train by type of train.

\begin{tabular}{|c|c|c|c|c|}
\hline \multirow{2}{*}{ No. } & \multirow{2}{*}{ Activity } & \multicolumn{3}{|c|}{ Type of service } \\
\hline & & $\mathbf{A}$ & B & C \\
\hline 1 & Reception of trains at Laem Chabang station & 124.6489 & 124.6489 & 124.6489 \\
\hline 2 & Train awaiting for service & & 34.9406 & 34.9406 \\
\hline 3 & Reception of trains at Laem Chabang Port station & & 89.0454 & 89.0454 \\
\hline \multirow{3}{*}{4} & \multirow{3}{*}{ Shunting operation } & 415.0986 & & \\
\hline & & & 151.7584 & \\
\hline & & & & 153.9139 \\
\hline \multirow[b]{2}{*}{5} & \multirow{2}{*}{ Train coordination } & 911.4522 & & \\
\hline & & & 195.5212 & 195.5212 \\
\hline 6 & Dispatch of trains from Laem Chabang Port station & & 89.0454 & 89.0454 \\
\hline 7 & Dispatch of trains from Laem Chabang station & 124.6489 & 124.6489 & 124.6489 \\
\hline \multicolumn{2}{|r|}{ Cost of service (Baht/Train) } & $1,575.85$ & 809.61 & 811.76 \\
\hline
\end{tabular}

\section{Conclusions}

From calculation cost of service of Laem Chabang train station by applying activity-based costing, the cost of activity for each type of train is revealed. The cost of service for oil train is $1,575.85$ baht per train, for 
container train entering zone B port is 809.61 baht per train and for container train entering zone C port is 811.76 baht per train.

From the above information, cost of service for oil train is found to be the highest due to its lower client which is about one-eighth of container train; that is conforms to the law of demand and supply. In order to reduce cost, it can be considered to operate more oil trains or to decrease the number of labour related to oil train because most of the cost occurs from labor salary (about $83 \%$ ). Thus, optimization of labour can clearly lower overall cost. However, rail transportation show to grow in the future. Even if the number of worker cannot be reduced, overall cost of the station will decrease due to the increase of transportation so Laem Chabang train station and container transportation office must retain the number of labour in order to support that expansion in the future which will result in increasing of profit per train.

\section{References}

[1] H. T. Johnson, "The decline of cost management: A reinterpretation of $20^{\text {th }}$ century cost accounting history," Journal of Cost Management, pp. 5-12, Spring 1987.

[2] K. E. David and L. J. Robert, "Why Is 'Integrated' ABC Better?," Journal of Corporate Accounting \& Finance, pp. 45-53, March/April 2002.

[3] H. T. Johnson, "Activity-Based Management: Past, Present, and Future," The Engineering Economist, vol. 36, no. 2, pp. 219-238, Spring 1991.

[4] B. Ruth. (2006). Logistic cost analysis by activity-based costing. Bangkok: The Japan External Trade Organization [JETRO Bangkok].

[5] A. Suppakarn, "Activity-based costing analysis for the trucking business," M.S. thesis, Chulalongkorn University, Bangkok, 2001.

[6] B. Adil and K. Vahit, "Application of activity-based costing to a land transportation company: A case study,” IE. Dept., Gaziantep Univ., Gaziantep Tyrkey, 2008.

[7] W. Pimchanok, "Activity-based costing model for distributing business," M.S. thesis, Chulalongkorn University, Bangkok, 2005.

[8] M. Marivic, "Activity based costing $(\mathrm{ABC})$ vs. traditional cost accounting system among top 500 corporations in the Philippines," College of Business and Economics, De La Salle University, Manila, 2004.

[9] H. R. Garrison and E. W. Noreen, Managerial Accounting, 9th ed. Boston: Irwin McGraw-Hill, 2000. 